\title{
Morphological Aspects of the Propagation in Heliconia velloziana L. Emygd. (Zingiberales: Heliconiaceae)
}

\author{
Daniela G. Simão* and Vera L. Scatena \\ Departamento de Botânica; Universidade Estadual Paulista; C. P. 199; 13506-900; dgsimao@rc.unesp.br; Rio \\ Claro - SP - Brasil
}

\begin{abstract}
Morphology of seed and vegetative propagation was studied to Heliconia velloziana L. Emygd. (Heliconiaceae), a rhizomatous herb with a large aerial part. Seeds took about four months to germinate, probably due to the undifferentiated embryo and hard endocarp. Seedlings had two first foliar structures as scale leaves and the primary root developed, but the adventitious roots were more conspicuous. Vegetative propagation by rhizomes was faster than the sexual one. The roots developed after one month, while young shoots started developing after four to six weeks; young aerial shoots presented a variable number of cataphylls and two protophylls.
\end{abstract}

Key words: Heliconia, rhizomes, seedlings, seed propagation, vegetative propagation

\section{INTRODUCTION}

The family Heliconiaceae comprises a single genus, Heliconia L. with 250-300 species distributed primarily in Neotropical areas from the North of Mexico to the South of Brazil (Santos, 1978; Dahlgren et al., 1985; Kress, 1990). A small Paleotropical group, about eight species, occurs in islands of the South Pacific (Tomlinson, 1969; Kress, 1985). There are approximately 40 Brazilian species with two primary areas of distribution: the Amazon basin and the Atlantic coastal forest (Kress, 1990). H. velloziana is an endemic species from the Atlantic forest and occurs from the Southeast to the South of Brazil (Mello-Filho, 1975; Santos, 1978; Citadini-Zanette and Baptista, 1989). Species of Heliconia are utilized as ornamental plants, usually being grown both as landscaping plants and as cut flowers (Castro and Graziano, 1997). The number of species commercially used has increased, mainly as cut flowers, because of the colour and the longer durability of their floral bracts (Castro, 1995). These species can be propagated by seeds or by rhizomes (Criley, 1988; Castro, 1995; Castro and Graziano, 1997). As most of the cultivated Heliconia species set few fruits or are sterile and the germination of the seeds is slow, the vegetative propagation by division of rhizomes is preferred in its commercial production (Montgomery, 1986; Criley, 1988; Lee et al., 1994). Another propagation method recently utilized is the tissue culture from axillary and terminal buds of rhizomes (Nathan et al., 1992; Goh et al., 1995; Kumar et al., 1996; Marangoni et al., 1999).

In species of Heliconiaceae there have been few detailed studies about seed and seedling morphology (e.g., Humphrey, 1896; Boyd, 1932; Tillich, 1995), although the vegetative propagation by rhizomes has achieved better attention (e.g., Criley, 1988; 1995; Geertsen, 1989; 1990; Castro, 1995). Morphological studies of monocotylous

\footnotetext{
*Author for correspondence
} 
seeds and seedlings have been regarded nowadays as an important source of taxonomical characters (Danilova et al., 1995; Tillich, 1995; 1996). The studies of vegetative propagation cited above are related to cultural methods, such as temperature, light, and not to the morphological aspects of the propagation. Therefore to understand the morphological aspects of the propagation in Heliconia, we undertook the studies on the morphology of the post-seminal development and the vegetative propagation of $H$. velloziana $\mathrm{L}$. Emygd.

\section{MATERIALS AND METHODS}

\section{Seed Propagation}

Ripe and young fruits were collected at "Núcleo Picinguaba", which is an environmental protection area around 8.500 ha and is located in the municipality of Ubatuba, State of São Paulo, Brazil, belonging to the "Serra do Mar" State Park. These fruits were collected and immediately stored in plastic bags. In the laboratory, the fleshy part of the fruits was removed and the seeds were sterilized in $10 \%$ sodium hypochlorite for five minutes, then washed in distilled water. The seeds were stored in plastic bags with moist vermiculite in a greenhouse at $25-30^{\circ} \mathrm{C}$ until germination was observed in some seeds (Criley, 1988; 1995). The germinated seeds were transferred to Gerbox with moist vermiculite for the post-seminal development studies. Observations were done every two days, until the nomophyll appeared in the plants. Different stages of development were illustrated under an Olympus SZH10 stereo microscope. The emerged cotyledonary sheath was used to define the germinated seeds.

\section{Vegetative Propagation}

Portions of the rhizomes with the aerial part were collected from clumps in the natural populations at "Núcleo Picinguaba". These were standardized with $10-15 \mathrm{~cm}$ in length of the rhizome and with $15-30 \mathrm{~cm}$ from the basal part of the aerial shoot (Criley 1988; 1995). These were then sterilized in $25 \%$ sodium hypochlorite for five minutes, and washed in distilled water. The roots were removed and the segments were transferred to plastic bags with vermiculite and Plantmax (1:1). These rhizome segments were stored in a greenhouse and monthly taken off for morphological observations. The terminology of the foliar structures was according to Alquini (1988).

\section{RESULTS}

Heliconia velloziana L. Emygd. is a herb with 2.20-3.50 m of height. The subterranean part of this plant is characterized by rhizomes with very short internodes, which bear adventitious roots. The aerial part is characterized by leaves, scape and a compound inflorescence. The inflorescence is terminal with an erect orientation and it is composed by 8-10 cymbiform distical orangishred bracts. Each bract involves one cincinnus, with about 10 greenish-yellow flowers per bracts. Floral buds and flower at anthesis and fruits in many developmental stages can be observed in the same cincinnus (Fig. 1). In $H$. velloziana the ovary was inferior, and trilocular, showing a single anatropous ovule of basal placentation in each locule (Figs. 2-3, 6). At the locular region, in cross section, the external layer of the ovary was thin and yellowish; the median and inner regions were thicker than the external one (Figs. 2-3).

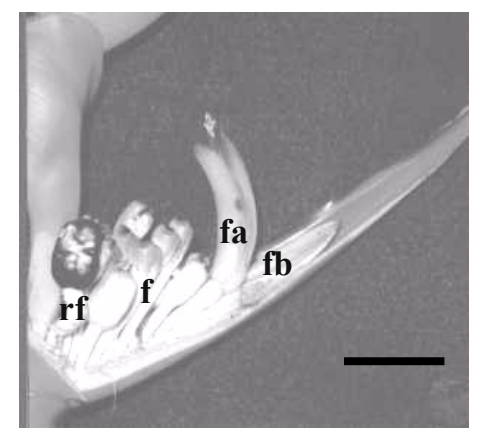

Figure 1 - Detail of $H$. velloziana cincinnus. The bract has been cut to show the cincinnus. $f=$ green fruits; $f a=$ floral anthesis; $\mathrm{fb}=$ flower buds; $\mathrm{rf}=$ ripe fruit. Scale bar $=2 \mathrm{~cm}$.

The fruit was a trilocular drupe, and had an obconic shape, with about $2.5 \mathrm{~cm}$ in length (Fig. 1). It generally presented three seeds, but some smaller fruits had only one or two seeds (Figs. 6-7). In the young stage, the epicarp had a greenish colour. The ripe epicarp had a bright blue colour, being smooth and thin (Fig. 1). The endocarp became lignified as the fruit develops, adhering closely to the integument of the seed, filling all the locule (Figs. 4-7). 


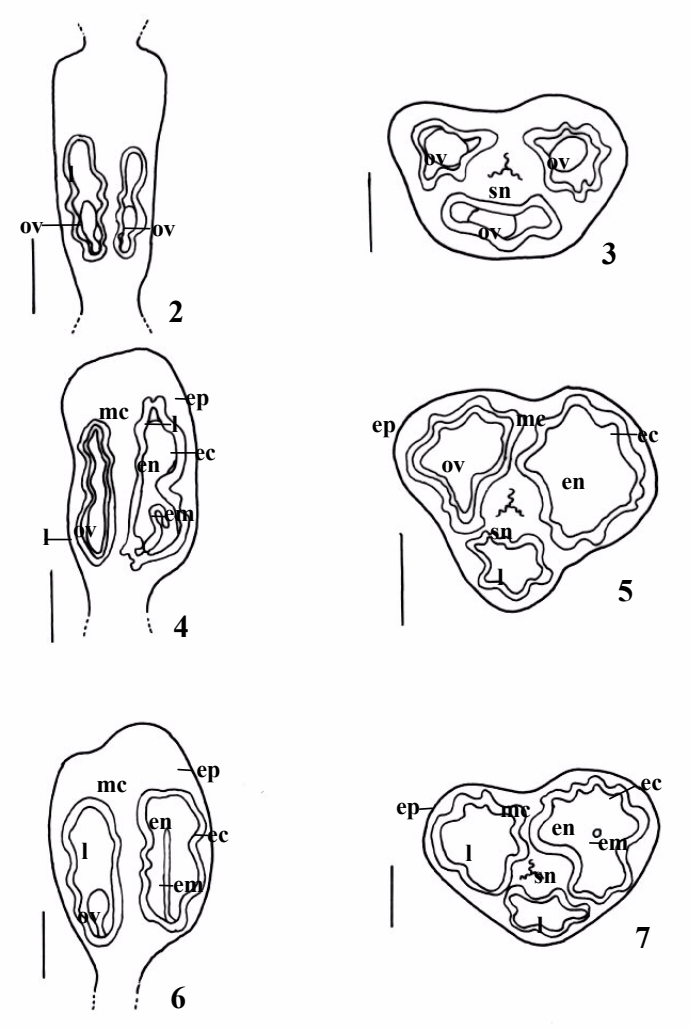

Figures 2-7 - Diagrams of longitudinal (Figs. 2, 4, 6) and cross (Figs. 3, 5, 7) sections of the median portion of the ovary, young and ripe fruit, respectively, of $H$. velloziana. $\mathrm{ec}=$ endocarp; em= embryo; en= endosperm; $\mathrm{ep}=$ epicarp $; \mathrm{l}=$ locule $; \mathrm{mc}=$ mesocarp; $\mathrm{ov}=$ ovule; sn $=$ septal nectary. Scale bars: Figs. 2, 4 and $6=$ $5 \mathrm{~mm}$; Fig. $3=2 \mathrm{~mm}$; Figs. 5 and $7=3 \mathrm{~mm}$.

The seed was involved by a stony endocarp, both constituting the diaspore, which measured about $1.0 \mathrm{~cm}$ in length and $0.5 \mathrm{~cm}$ in width, presenting an elliptical shape and a wrinkled surface (Figs. 8-9). Ventral side of the diaspore was plain (Fig. 8), while the dorsal one was convex (Fig. 9). An operculum was localized on the ventral side of the diaspore basal portion (Fig. 8). The seed was also elliptical in shape and had a thin integument. The embryo presented an elongated structure in the longitudinal view (Fig. 6), and it was yellowish, darker than the endosperm.

\section{Seed Propagation}

The germination period occurred about four months after the embedded seed. Some seeds germinated only after six months. The germination was hypogeal and the seedling was cryptocotyledonar. The whitish cotyledonary sheath emerged, displacing the operculum (Fig. 10). This cotyledonary sheath had many trichomes in contact with the substract. At this stage, the operculum could be adhered (Fig. 10), or not, to the cotyledonary sheath.

The primary root developed in the centre of the absorbing trichomes, at the basal portion of the cotyledonary sheath (Fig. 11). The apical portion of this sheath also developed, tapering (Fig. 12) and getting a greenish colour. After 8-10 days, the primary root was larger (Fig. 12) and presented a whitish colour. The first foliar structure, i.e. the protophyll, developed at the apex of the cotyledonary sheath (Fig. 12). The first adventitious roots started emerging at the base of the cotyledonary sheath. An increase of adventitious roots, both in number and size, was observed after 12-14 days (Fig. 13). After 16-18 days, the second foliar structure, $i$. e. the second protophyll, developed, and after 20-24 days it increased (Figs. 15-16).

Six days later, the third foliar structure, i.e. the nomophyll, was observed developing inside of the sheath of the second protophyll, which had a reduced blade (Figs. 17-18). The cotyledonary sheath became dry and the adventitious roots were about $4.5 \mathrm{~cm}$ in length (Fig. 17). After 30-32 days, a larger root emerged from the base of the first protophyll at the level of the cotyledonary sheath (Fig. 18 - arrow). The nomophyll continued to develop and after about 36 days, it was fully expanded (Fig. 18). Young adventitious roots originated while older ones continued their growth. At this stage, the cotyledonary sheath was totally dry (Figs. 18-19). Diasporal portions remained attached to the seedling during all these stages of post-seminal development (Figs. 10-19).

\section{Vegetative Propagation}

After one month of the setting of the experiment, young adventitious roots grew from the basal portion of both the young rhizomes (Figs. 20, 22) and the older ones, which had their aerial part cut off (Figs. 20-21, 23). The young units of rhizomes grew either at the distal portion (Fig. 22) or in opposite sides (Figs. 20-21, 23) from the original unit.

The young shoots developed from the whitish buds, generally in the same region of the basal portion of the older rhizome segments, as by the adventitious roots (Figs. 20-21, 23). Then, these buds lengthened, and became greenish colour. It 
was possible to observe the foliar structure disposition in young shoot (Fig. 23).

In the young shoots, a variable number of cataphylls were formed, followed by two protophylls, and only the second one of these developed foliaceous apex (Figs. 20-21). After that the nomophylls, i.e. the mature leaves, presented a leaf sheath, petiole and blade (Figs. 20-21). Young convolute leaves emerged showing a transparent foliar margin and a precursor tip at the distal end. These young leaves took about one month to be totally exposed (from the development of the precursor tip until the complete expansion of the foliar blade). At this time, the precursor tip started to dry.

\section{DISCUSSION}

The fruit in Heliconiaceae species has been previously named as loculicidal (Humphrey, 1896; Nakai, 1941) or septicidal capsules (Tomlinson, 1959), berry (Lane, 1955; Barreiros, 1970) and schizocarp fruit (Tomlinson, 1962; Barreiros, 1974). The results found in $H$. velloziana confirmed that fruits of Heliconia were drupes (Santos, 1978; Cronquist, 1981; Dahlgren et al. 1985). The fruit was a drup in wide sense (Font Quer, 1985), because it was an indehiscent fleshy fruit with a lignified endocarp.

The presence of a hard integument in Heliconia seeds was mentioned by Lane (1955), Barreiros (1970) and by Criley $(1988 ; 1995)$. What these authors called hard integument, was in fact the lignified endocarp. It remained adhered to the seed, constituting a unit of dispersion as seen here in fruits of $H$. velloziana and as cited earlier by Humphrey (1896), Santos (1978), and Kirchoff (1992).

The endocarp may be functioning as a hard coat, protect against unfavourable environmental conditions, predator insects and the digestive tract of dispersers. According to Barreiros (1972) and Montgomery (1986), diaspores of Heliconia species, i.e., the lignified endocarp adhered to the seed, passed through the digestive tract of frugivorous birds, and later were dispersed (Barreiros, 1974; Mello-Filho and Santos, 1987). Novaes (1975) also suggested that frugivorous birds utilized the diaspores as a grind material in its mechanical digestive tract. However according to Stiles (1985), these birds feed from the fleshy part of the fruits and then regurgitate the seeds.

In some monocotyledons with indehiscent fruits, the protective function is done by the pericarp, although in the majority of the monocotyledons, it is done by the seed coat (Danilova et al., 1995). According to them this is observed in seeds with a specialized pericarp, as found in Potamogetonaceae, Ruppiaceae (Alismatidae) and certain Poaceae.

But this protection done by the hard endocarp which can also represent a barrier for the embryo, making difficult a fast germination, as suggested by Graven et al. (1996) in the species of Musaceae. Seeds germination in $H$. velloziana took about four months. This germination period seemed long, but it confirmed the data found in literature. These data showed a long germination to some species of this family, including species that took three years to germinate (Montgomery, 1986; Criley, 1988; Castro, 1995). Montgomery (1986) reported that the range in the germination period of Heliconia (from three months to three years), depended on the degree of the embryo development at the time of the fruit maturity. Species from moist places usually took lesser time to germinate, while those from dry areas took longer, until the environmental conditions were favourable. Although $H$. velloziana occurs in moist places and takes four to six months to germinate, suggesting that other environmental factors, as e. g. temperature, or even other factors, such as the development of the embryo, could influence the begining of the germination period.

Due to the little disponibility of the seeds at the study site, we did not have enough seeds to make germination tests, as the scarification of the endocarp. But according to Criley (1988), the scarification did not hasten germination in species of Heliconia. Graven et al. (1996) also reported that the removal of the operculum did not increase or accelerate the germination in species of Musaceae. They related that with this removal, water reached the embryo but could not hydrate it, probably showing that in both families (Heliconiaceae and Musaceae) the embryo had dormancy at the time of the fruit maturity.

According to Humphrey (1896) the operculum, which he named sclerotic plug, was formed from the funiculus after the development of the seed and the endocarp. This structure served as protection, being pushed by the embryo growth, while the endocarp protected the remainder of the cotyledon. 


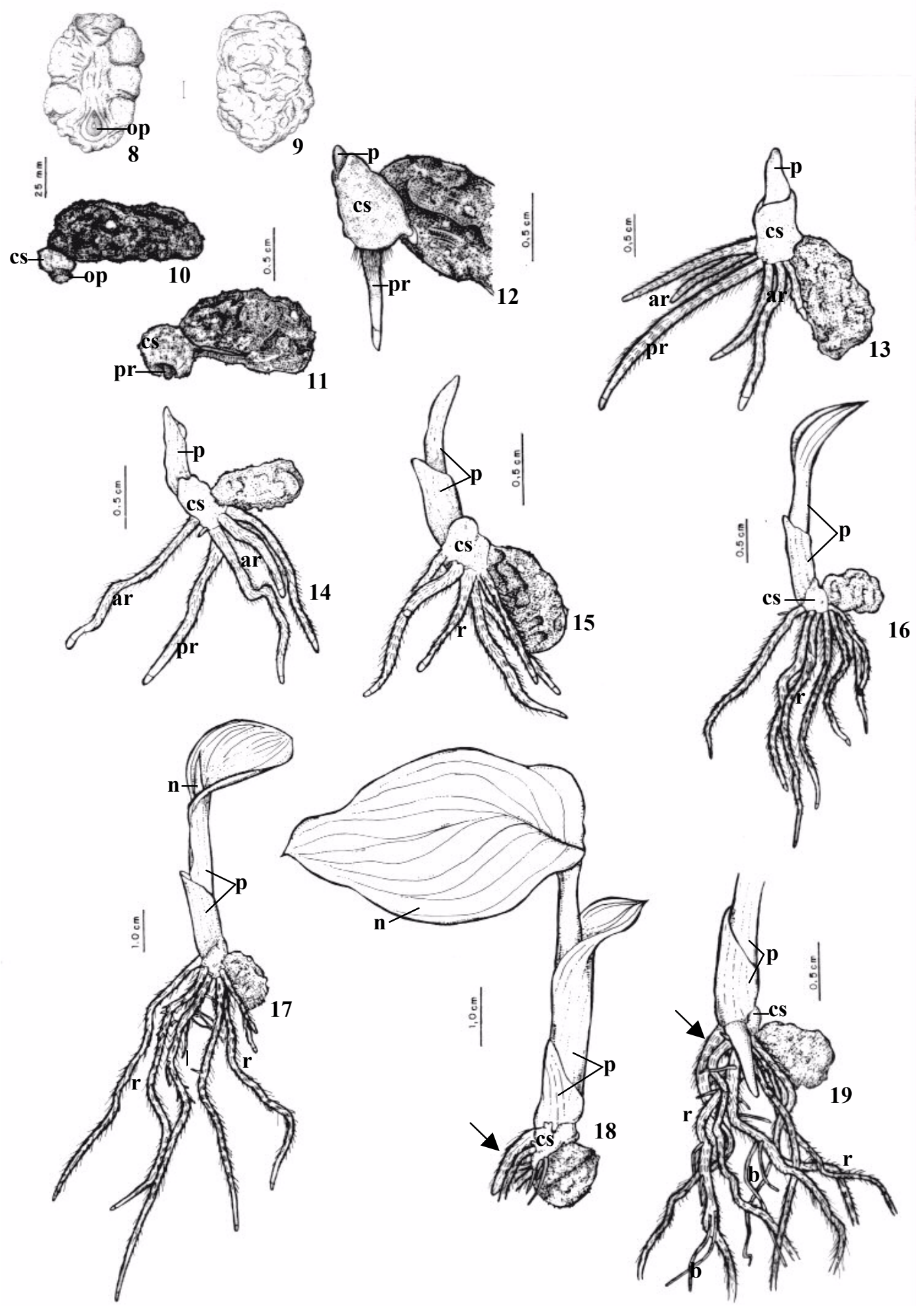

Figures 8-19 - Post-seminal development of H. velloziana. Ventral (Fig. 8) and dorsal (Fig. 9) views of the diaspore. Beginning of the germination period (Figs. 10-11). Seedlings with 8-10 days (Fig. 12); 12-14 days (Fig. 13); 16 -18 days (Fig. 14); 20-24 days (Figs. 15-16); 26-30 days (Fig. 17) and 32-36 days (Fig. 18). Detail of roots with 32-36 days (Fig. 19). ar= adventitious roots; $b=$ branching roots; $c s=$ cotyledonary sheath; $n=$ nomophyll; op= operculum; $\mathrm{p}=$ protophyll; $\mathrm{pr}=$ primary root; $\mathrm{r}=$ roots; arrows= larger roots. 


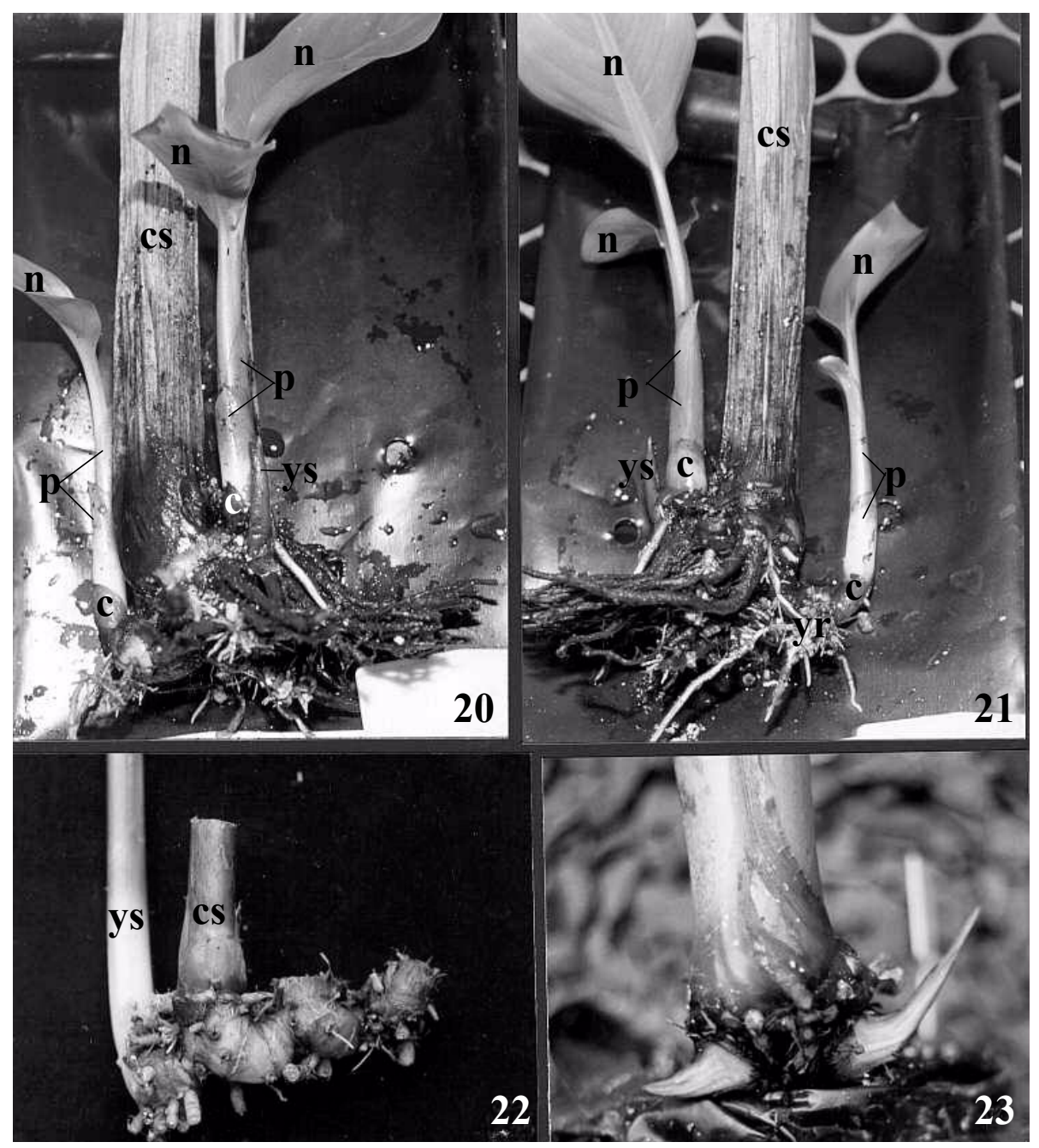

Figures 20-23 - Vegetative propagation of $H$. velloziana. Development of two young aerial shoots grown in opposite sides from the older rhizome (Figs. 20-21). Young segment of rhizome grown at the distal portion; roots were removed for a better viewing of the rhizomes (Fig. 22). Two young shoots growing in opposite sides at the basal portion of the rhizome; roots were removed for a better viewing of the rhizome (Fig. 23). $\mathrm{c}=$ cataphyll; $\mathrm{cs}=\mathrm{cut}$ shoot; $\mathrm{n}=$ nomophyll; $\mathrm{p}=$ protophyll; $\mathrm{yr}=$ young roots; $\mathrm{ys}=$ young aerial shoot.

Danilova et al. (1995) reported that the operculum was found in certain monocotyledons, and was more developed in representatives of some families of Zingiberales and Commelinales.

In relation to seedlings, Tillich (1995) showed a morphological range in seedlings development of several monocotylous species. Among these two species of Heliconia with characteristics such as: adventitious roots more conspicuous than the primary root and the apical split of the cotyledonary sheath were similar to those observed in $H$. velloziana.

Tillich (1995) reported that Zingiberales, to which order the Heliconiaceae belonged, was a well defined order in relation to the morphology of seedlings, except from Costaceae which had a different seedling structure. He also reported that the coleoptile was commonly present in all Zingiberales species, which presence was considered a highly derived condition, being absent only in Heliconiaceae. On the other hand he affirmed that this character needs verification since he investigated only two species in all family. The present study confirmed this hypothesis because $H$. velloziana also did not have a coleoptile.

In relation to seedlings, Boyd (1932) related that in the order Zingiberales, species of Cannaceae and Zingiberaceae had the two first foliar organs as scale leaves. This kind of leaves were observed in 
H. velloziana, the first and the second one presenting a reduced blade. The presence of these scale leaves in monocotyledons seedlings was treated as an ancestral condition by Tillich (1996). In relation to the vegetative propagation, the rhizomes of the Heliconia species studied by Criley $(1988 ; 1995)$ took about one month to develop young roots and four to six weeks to the activation of the buds. We observed the same on young roots and aerial shoots of $H$. velloziana, which also started its developments during this same period of time.

Young roots did not develop at the beginning of the growth of young shoots in $H$. velloziana rhizomes. The same was observed by LaFrankie (1985) in Smilacina racemosa (Liliaceae), probably showing that there was a dependence of the young shoots on the adult rhizome, besides a close association of these units. The development of the young roots both from the node and internode regions in $H$. velloziana was also observed in other monocotyledons such as Smilacina racemosa by LaFrankie (1985) and in Musa rosacea (Musaceae) by Alquini (1988).

In Poa pratensis (Poaceae) the first foliar structure of the axilar bud was the cataphyll (Fisher, 1972). These foliar structures were also observed in $H$. velloziana rhizomes, protecting the bud on the beginning of its development. We also observed a second type of foliar structure, which Alquini (1988) named protophylls, protecting the young leaves. The first protophylls usually presented only the basal portion developed, while the following ones presented part of the apical portion developed. In $H$. velloziana, the second protophyll had a reduced blade, in the seedlings as well in the young shoot of the rhizome. Young leaves of Musa remained totally rolled up inside the leaf sheath, until the blade of the precedent leaf was completely developed (Barker and Steward, 1962). This also occurred in $H$. velloziana. All Zingiberales species studied by Skutch (1930) also had convolute leaves at the prefoliation, and practically all of them were developed at the time of the emergence.

\section{ACKNOWLEDGEMENTS}

We thank the Brazilian Research Council (Conselho Nacional de Desenvolvimento Científico e Tecnológico, CNPq) for supporting this study; to A. Mantovani for helping with the final lay-out; and to C. Burgess for the English review.

\section{RESUMO}

A morfologia da propagação por sementes e da propagação vegetativa foi estudada em Heliconia velloziana L. Emygd. (Heliconiaceae). As sementes levaram cerca de quatro meses para germinar, provavelmente pelo embrião indiferenciado na época da maturação do fruto e também devido ao endocarpo pétreo, que envolve a semente. As duas primeiras estruturas foliares nas plântulas são escamiformes e as raízes adventícias são mais conspícuas do que a raiz primária. Na propagação vegetativa as raízes se desenvolveram a partir de quatro semanas e os brotos a partir de quatro a seis semanas; inicialmente foram formados os catafilos, e depois dois protofilos.

\section{REFERENCES}

Alquini, Y. (1988), Interpretação morfológica de Musa rosacea Jacq. (Musaceae) - Fase teleomática. Acta bot. bras., 1, 125-142.

Barker, W. G. and Steward, F. C. (1962), Growth and development of the banana plant - I. The growing regions of the vegetative shoot. Ann. Bot., 26, 389-411.

Barreiros, H. S. (1970), Notas sobre Heliconia linneana Lane in herb. Rev. Brasil. Biol., 30571-573.

Barreiros, H. S. (1972), Heliconia Nova Brasiliana et Varietas (Heliconiaceae (End.) Nakai) - III. Rev. Brasil. Biol., 32, 205-208.

Barreiros, H. S. (1974), Novas localidades de ocorrência de Heliconia L. - I (Heliconiaceae). Bradea, 1, 447-452.

Boyd, L. (1932), Monocotylous seedlings. Morphological studies in the post-seminal development of the embryo. Trans. and Proc. Bot. Soc. Edinburgh, 305-224.

Castro, C. E. F. (1995), Helicônia para exportação: aspectos técnicos da produção. EMBRAPA-SPI, Brasília, DF.

Castro, C. E. F. and Graziano, T. T. (1997), Espécies do gênero Heliconia (Heliconiaceae) no Brasil. Rev. Bras. Hortic. Ornam., 3, 15-28.

Citadini-Zanette, V. and Baptista, L. R. M. (1989), Vegetação herbácea terrícola de uma comunidade florestal em Limoeiro, município de Torres, RS, Brasil. B. Inst. Bioc., 451-87. 
Criley, R. A. (1988), Propagation of tropical cut flowers: Strelitzia, Alpinia and Heliconia. Acta Hort., 226, 509-517.

Criley, R. A. (1995), Propagation of Zingiberaceae and Heliconiaceae. Rev. Bras. Hort. Orn., 1, 14-21.

Cronquist, A. (1981), An integrated system of classification of flowering plants. Columbia University Press, New York. pp. 1157-1172.

Dahlgren, R. M. T., Clifford, H. T. and Yeo, P. F. (1985), The families of the monocotyledons. SpringerVerlag, Berlin. pp. 350-358.

Danilova, M. T., Nemirovich-Dannchenko, E. N., Komar, G. A. and Lodkina, M. M. (1995), The seed structure of monocotyledons. In: Rudall, P. J.; Cribb, P. J.; Cutler, D. F. and Humphries, C. J. (eds.). Monocotyledons: systematics and evolution. Royal Botanic Gardens, Kew. pp. 461-472.

Fisher, J. E. (1972), Structural positioning and orientational development in the vegetative organs of Poa pratensis with special references to the rhizome axillary buds. Can. J. Bot., 50743-750.

Font Quer, P. (1985), Diccionario de Botánica. Barcelona : d. Labor.

Geertsen, V. (1989), Effect of photoperiod and temperature on the growth and flower production of Heliconia psittacorum 'Tay'. Acta Hort., 252, 117-122.

Geertsen, V. (1990), Influence of photoperiod and temperature on the growth and flowering of Heliconia aurantiaca. HortScience, 25, 646-648.

Goh, C. J., Nathan, M. J. and Kumar, P. P. (1995), Direct organogenesis and induction of morphogenic callus through thin section culture of Heliconia psittacorum. Scientia Horticulturae, 62, 113-120.

Graven, P., Koster, C. G., Boon, J. J. and Bouman, F. (1996), Structure and macromolecular composition of the seed coat of the Musaceae. Ann. Bot., 77, 105-122.

Humphrey, J. E. (1896), The development of the seed in the Scitamineae. Ann. Bot., 10, 1-40.

Kirchoff, B. K. (1992), Ovary structure and anatomy in the Heliconiaceae and Musaceae (Zingiberales). Can. J. Bot., 702490-2508.

Kress, W. J. (1985), Bat pollination of an Old World Heliconia. Biotropica, 17, 302-308.

Kress, W. J. (1990), The diversity and distribution of Heliconia (Heliconiaceae) in Brazil. Acta Bot. Bras., 4, 159-167.

Kumar, P. P., Nathan, M. J., and Goh, C. J. (1996), Involvement of ethylene on growth and plant regeneration in callus cultures of Heliconia psittacorum L.f. Plant Growth Regulation, 19, 145-151.

LaFrankie, J. V. (1985), Morphology, growth, and vasculature of the sympodial rhizome of Smilacina racemosa (Liliaceae). Bot. Gaz., 146, 534-544.

Lane, I. E. (1955), Genera and generic relationships in Musaceae. Mitt. Bot. Staatsamml. München, 13, 114-131.

Lee, Y. H.; Ng, N. Y. and Goh, C. J. (1994), Pollen formation and fruit set in some cultivars of Heliconia psittacorum. Scientia Horticulturae, 60167-172.
Marangoni, A.; Pedrotti, E. L. and Maraschin, M. (1999), Controle do processo de oxidação de explantes para cultivo in vitro de Heliconia angusta (resumo). In: Anais... Congresso Brasileiro de Floricultura e Plantas Ornamentais, 12, Jaboticabal. pp. 115.

Mello-Filho, L. E. (1975), O gênero Heliconia na Flora Fluminensis de Frei José Mariano da Conceição Vellozo. Rev. Brasil. Biol., 35331-337.

Mello-Filho, L. E. and Santos, E. (1987), Heliconiae novae brasiliensis VIII. Bradea, 4, 95-104.

Montgomery, R. (1986), Propagation of Heliconia from seeds. Bull. Heliconia Soc. Inter., 1, 6-7.

Nakai, T. (1941), Notulae ad Plantas Asiae Orientalis. Jour. Japanese Bot., 17, 1-15.

Nathan, M. J., Goh, C. J. and Kumar, P. P. (1992), In vitro propagation of Heliconia psittacorum by bud culture. Hortscience, 27, 450-452.

Novaes, D. S. (1975), Anatomia do ovário de Heliconia angusta Vell. (resumo). An. Acad. Bras. Ci., 47, 572-573.

Pereira, T. S. (1988), Bromelioideae (Bromeliaceae): Morfologia do desenvolvimento pós-seminal de algumas espécies. Arch. Jard. Bot. RJ, 29115-154.

Santos, E. (1978), Revisão das espécies do gênero Heliconia L. (Musaceae s.l.) espontâneas na região fluminense. Rodriguésia, 30, 99-201.

Skutch, A. F. (1930), Unrolling of leaves of Musa sapientum and some related plants and their reactions to environmental aridity. Bot. Gaz., 90, 337-365.

Stiles, F. G. (1985), The natural history of Heliconia in Costa Rica (abstract). Bull. Heliconia Soc. Inter., 1, 7.

Tillich, H. J. (1995), Seedlings and systematics in monocotyledons. In: Rudall, P. J.; Cribb, P. J.; Cutler, D. F. and Humphries, C. J. (eds.). Monocotyledons: systematics and evolution. Royal Botanic Gardens, Kew. pp. 303-352.

Tillich, H. J. (1996), Seeds and seedlings in Hanguanaceae and Flagellariaceae (Monocotyledons). Sendtnera, 3, 187-197.

Tomlinson, P. B. (1959), An anatomical approach to the classification of the Musaceae. J. Linn. Soc. (Bot.), 55, 779-809.

Tomlinson, P. B. (1962), Phylogeny of the Scitamineae - morphological and anatomical considerations. Evolution, 16, 192-213.

Tomlinson, P. B. (1969), Commelinales-Zingiberales. In: Metcalfe, C. R. (ed.). Anatomy of the Monocotyledons. Oxford University Press. pp. 295-324.

Received: October 03, 2000; Revised: March 06, 2001; Accepted: September 25, 2001. 